\title{
Mechanism of Huiru decoction on hyperprolactinemia in rats
}

\author{
Shufang Yang ${ }^{1 *}$ and Bin $\mathrm{Wu}^{2}$ \\ ${ }^{1}$ Department of Endocrinology, Taizhou People's Hospital, Taizhou 225300, Jiangsu, ${ }^{2}$ Department of Rheumatology, \\ Chongqing Chinese Medicine Hospital, Chongqing 400021, China \\ *For correspondence: Email: yangshufang133494@163.com; Tel: +86 0523-82182831
}

\begin{abstract}
Purpose: To investigate the anti-hyperPRL mechanism of traditional Chinese medicine Huiru Decoction $(H D)$ in rats.

Methods: The effect of HD on serum prolactin (PRL), estradiol (E2), progesterone (PGN), follicle stimulating hormone $(F S H)$ and luteinizing hormone $(\mathrm{LH})$ levels were investigated in hyperprolactinemia (hyperPRL) rats. Furthermore, the effect of HD on hypothalamus dopamine D2 receptor, protein kinase $A(P K A)$ and cyclic adenosine monophosphate (CAMP) levels of hyperPRL rats were investigated respectively.

Results: Compared with the model group, a high dose of HD (19.2 g/kg body weight) and medium dose of HD $(9.6 \mathrm{~g} / \mathrm{kg}$ body weight) reduced PRL level of hyperPRL rats effectively $(p<0.01)$. HD increased dopamine D2 receptor $(p<0.01)$, reduced cAMP $(p<0.01)$ and PKA $(p<0.01)$ levels of hypothalamus in hyperPRL rats significantly.

Conclusions: HD showed anti-hyperPRL activity via dopamine $D 2$ receptor.
\end{abstract}

Keywords: hyperprolactinemia; Huiru Decoction; dopamine D2 receptor

Tropical Journal of Pharmaceutical Research is indexed by Science Citation Index (SciSearch), Scopus, International Pharmaceutical Abstract, Chemical Abstracts, Embase, Index Copernicus, EBSCO, African Index Medicus, JournalSeek, Journal Citation Reports/Science Edition, Directory of Open Access Journals (DOAJ), African Journal Online, Bioline International, Open-J-Gate and Pharmacy Abstracts

\section{INTRODUCTION}

Hyperprolactinemia, which is one of the most common endocrine disorders of the hypothalamus-pituitary axis (PRL $>25 \mathrm{ng} / \mathrm{mL})$ in young women, is associated with galactorrhea and ovulatory dysfunction that results in menstrual irregularities [1]. HyperPRL can occur at any age, and the prevalence varies from $0.4 \%$ in the normal adult population to as high as 9-17 $\%$ in women with menstrual problems such as amenorrhea or polycystic ovarian syndrome $[2,3]$. Common causes which induce hyperPRL are hypothalamus-pituitary lesions, pituitary tumor, severe liver or kidney disease, neuritis or irritations of the spinal cord, depression or other physiological factors such as pregnancy and lactation [4,5]. Galactorrhea is a common kind of female disease induced by hyperPRL. Synthetic drugs are used in treating them, but they always bring many side effects such as menstrual disorder and the relapse rate is very high. Bromocriptine and cabergoline are effective in curing hyperPRL, but $12 \%$ patients cannot endure bromocriptine [6].

Empirical evidence suggests that many herbal medicines possess the therapeutic potential to alleviate hyperPRL symptoms [8]. In China, Huiru Decoction (HD) is composed of Chai $\mathrm{Hu}$ (Bupleurum chinense DC.) $60 \mathrm{~g}$, Xia Ku Cao (Prunella vulgaris L.) $15 \mathrm{~g}$, Xiangfu (Cyperus rotundus L.) $12 \mathrm{~g}$, Danpi (Tree Peony Bark) $10 \mathrm{~g}$, Gancao (Glycyrrhiza uralensis Fisch) $10 \mathrm{~g}$ and 
Dan Shen (Salvia miltiorrhiza Bge.) $10 \mathrm{~g}$. It is often used to treat galactorrhea effectively without toxic side effect. In previous study, we found that HD could decrease prolactin level in hyperPRL mice effectively [9]. However, the antihyperPRL mechanism of it was still unknown.

In order to clarify the mechanisms underlying the anti-hyperPRL effects of HD, we planned a direct experimental test. Most conventional antihyperPRL agents reduce PRL secretion through D2 receptor agonism in the hypothalamic neuroendocrine dopaminergic system, and cAMP/PKA signal transduction pathway is one of dopamine receptor classic pathways [10]. And other sex-steroids other than PRL and DAT are also involved in the pathophysiology of hyperPRL [11]. Therefore, we hypothesized that the therapeutic efficacy of $\mathrm{HD}$ in alleviating hyperPRL could be attributed to modulation of dopamine D2 receptor. To test this hypothesis, we examined the effects of HD on dopamine D2 receptor, PKA and CAMP levels in a rat model of hyperPRL.

\section{EXPERIMENTAL}

\section{Preparation of HD}

The dried herbs of HD were decocted with 1000 $\mathrm{ml}$ water twice, $45 \mathrm{~min}$ for each. Then the liquor was filtrated by a funnel and concentrated into $200 \mathrm{ml}$ of HD. The HD was used for animal experiments.

\section{Experiment in animal model of hyperPRL}

Female Wistar rats weighing 200-220 g were obtained from Jiangsu Center for Disease Control and Prevention, Nanjing, Jiangsu. The animals had free access to food and water, and were allowed to acclimatize for at least one week before use. All experiments were approved by the Animal Care and Use Committee and were carried in compliance with the Animal Welfare Act and the $\mathrm{NIH}$ guidelines (NIH publication No.80-23, revised 1996).

Rats were given intraperitoneal (i.p.) of metoclopramide (MCP, $150 \mathrm{mg} / \mathrm{kg}$ daily) for 10 days to prepare hyperPRL model [12]. 60 rats were divided into six groups of ten individuals: control, model group, model plus positive drug bromocriptine group, plus high dose of HD (19.2 $\mathrm{g} / \mathrm{kg})$ group, plus middle dose of HD $(9.6 \mathrm{~g} / \mathrm{kg})$ group and plus low dose of HD $(4.8 \mathrm{~g} / \mathrm{kg})$ group. Each dose was dissolved in $2 \mathrm{~mL}$ of water, and given into rats by administered gavage. The dosage was calculated from the daily human AFH clinical dosage based on body surface area.
Control and model rats received $2 \mathrm{ml}$ of water. All group mice were intragastric administrated for 30 days.

\section{Sex hormones determination}

After the treatment of administrating for 30 days in hyperPRL rats, serum was obtained by eyeball removal. Serum PRL, E2, PGN, FSH and LH levels of the rats were measured by ELISA kits (Shenzhen Xin-Bo-Sheng Biological Technology Co., Ltd., China).

\section{Western blot analysis of hypothalamus dopamine D2 receptor}

Rat hypothalamus tissues were homogenized in $10 \mathrm{wt} / \mathrm{vol}$ RIPA buffer with protease inhibitor and centrifuged at $3000 \times \mathrm{g}$ for $15 \mathrm{~min}$ at $4{ }^{\circ} \mathrm{C}$. The supernatant samples were centrifuged at 12,000 $\times \mathrm{g}$ for $20 \mathrm{~min}$ at $4{ }^{\circ} \mathrm{C}$. The final peptides were dissolved in a RIPA buffer and loading buffer. After resolution of hypothalamus protein (equal loading for each sample) by $12 \%$ sodium dodecyl sulfate polyacryla-mide gel electrophoresis, the protein samples were transferred onto polyvinylidene difluoride membranes (Merck), respectively. Nonspecific protein-binding sites were blocked with phosphate-buffered saline containing $0.1 \%$ Tween-20 and $5 \%$ fat-free milk for $1 \mathrm{~h}$ at room temperature, and then incubated in appropriate primary antibodies (DRD2, 1: 1000; B-actin, 1: 5000). Immunoreactive bands were visualized by incubation with lumiGLO reagent (Cell Signaling) and exposed to X-ray film (Kodak, Stamford, CT, USA). Quantification of Western blot analysis was performed with ImageJ (National Institutes of Health, Bethesda, MD, USA). B-actin levels were used as a protein loading control. The relative levels of target proteins were determined after normalization with B-actin, respectively.

\section{Measurement of hypothalamus PKA and cAMP levels}

Rat brains were stripped and grinded into homogenate, then centrifugated for $15 \mathrm{~min}$ at $3000 \mathrm{r} \cdot \mathrm{min}^{-1}$. The supernatant was used to measure PKA and CAMP levels by ELISA kits (Shenzhen Xin-Bo-Sheng Biological Technology Co., Ltd., China).

\section{Statistical analysis}

Values are expressed as mean \pm SEM. Significant differences between the groups were analyzed using one-way analysis of variance 
(ANOVA) followed by two-paired Student's t-test. $P<0.05$ was considered statistically significant.

\section{RESULTS}

\section{Effect of HD on sex hormones in rat model of hyperPRL}

Compared with control group, serum PRL level of hyperPRL model rats increased significantly $(p<$ $0.01)$. Serum E2, PGN and FSH and LH ( $p<$ 0.05 ) levels of hyperPRL model rats decreased significantly $(p<0.01)$. Compared with model group, the increased PRL level was significantly attenuated by treatment with $0.6 \mathrm{mg} / \mathrm{kg}$ bromocriptine and 9.6 or $19.2 \mathrm{~g} / \mathrm{kg} \mathrm{HD}$ after 30 days $(p<0.01)$. And rat serum E2 level decreased $(p<0.01)$, and serum PGN, FSH and $\mathrm{LH}$ levels increased $(p<0.05)$ effectively in bromocriptine-treated group. Compared with model group, rat serum E2 level decreased ( $p<$ 0.01), and serum $\mathrm{P}, \mathrm{FSH}$ and $\mathrm{LH}$ levels increased $(p<0.05)$ significantly treated by highdose of HD (Table 1).

\section{Effects of HD on hypothalamus dopamine D2 receptor in rat model of hyperPRL}

Western blot analysis revealed that hypothalamus dopamine D2 receptor protein expression in model rats was much less than that in control rats $(p<0.01)$. Compared with model rats, such decreased dopamine D2 receptor protein were significantly improved by treatment with $0.6 \mathrm{mg} / \mathrm{kg}$ bromocriptine $(p<0.01)$ or 4.8 $\mathrm{g} / \mathrm{kg}(p<0.05)$ or $9.6 \mathrm{~g} / \mathrm{kg}(p<0.01)$ or $19.2 \mathrm{~g} / \mathrm{kg}$ $(p<0.01)$ HD for 30 days.

\section{Effect of HD on hypothalamus PKA and cAMP levels in rat model of hyperPRL}

Our study demonstrated that hypothalamus PKA $(p<0.01)$ and CAMP $(p<0.01)$ level in rat model of hyperPRL increased significantly compare to control group. Such increased PKA and cAMP were significantly attenuated by treatment with $0.6 \mathrm{mg} / \mathrm{kg}$ bromocriptine or $4.8 \mathrm{~g} / \mathrm{kg}(p<0.05)$ or $9.6 \mathrm{~g} / \mathrm{kg}(p<0.01)$ or $19.2 \mathrm{~g} / \mathrm{kg}(p<0.01) \mathrm{HD}$ for 30 days (Figure 1 ).

\section{DISCUSSION}

In previous study, we found that HD could decrease prolactin level in hyperPRL rats effectively. In this study, HD increased dopamine D2 receptor, reduced the hypothalamus cAMP and PKA levels in hyperPRL rats significantly.

Dopamine receptors belong to the family of seven transmembrane domain G-protein coupled receptors (GPCR) [13-15]. Dopamine receptors D1 and D2 are classified into two subfamilies based on their differential effect on adenylyl cyclase.

Classically, the functions of dopamine receptors have been associated with the regulation of adenylate cyclase-protein kinas A (cAMP-PKA) through G-protein-mediated signaling. Two classes of GPCR mediate dopamine functions, D1-like receptor subtypes (D1 and D5) couple mostly to Gas and stimulate the production of the second messenger cAMP and the activity of PKA. However, D2-like subfamily (D2, D3, and D4) couple to Gai/o and regulate the production of cAMP negatively, thus resulting in a diminution of PKA activity [16-18].

Table 1: Effect of HD on sex hormones in hyperPRL rats

\begin{tabular}{|c|c|c|c|c|c|}
\hline Group & $\begin{array}{c}\text { PRL } \\
\text { (pg/mL) }\end{array}$ & $\begin{array}{c}\text { E2 } \\
\text { (pmol/L) }\end{array}$ & $\begin{array}{c}P \\
(\mathrm{ng} / \mathrm{mL})\end{array}$ & $\begin{array}{l}\text { FSH } \\
\text { (IU/L) }\end{array}$ & $\begin{array}{c}\mathrm{LH} \\
(\mathrm{mlU} / \mathrm{mL})\end{array}$ \\
\hline Control & $201.17 \pm 6.35$ & $3.74 \pm 0.31$ & $1.37 \pm 0.06$ & $0.98 \pm 0.06$ & $1.86 \pm 0.16$ \\
\hline Model & $453.22 \pm 32.43^{* *}$ & $1.46 \pm 0.14^{* *}$ & $\begin{array}{l}0.53 \pm \\
0.12^{\star *}\end{array}$ & $\begin{array}{l}0.41 \pm \\
0.04^{\star *}\end{array}$ & $0.88 \pm 0.08^{*}$ \\
\hline Bromocriptine & $224.54 \pm 10.62^{\Delta}$ & $2.83 \pm 0.26 \Delta \Delta$ & $\begin{array}{l}0.84 \pm \\
0.05 \Delta\end{array}$ & $\begin{array}{l}0.77 \pm \\
0.03 \Delta\end{array}$ & $1.62 \pm 0.07 \triangleleft$ \\
\hline $\mathrm{HD}-\mathrm{H}$ & $221.16 \pm 12.36 \Delta$ & $2.59 \pm 0.18^{\Delta \Delta}$ & $\begin{array}{l}0.88 \pm \\
0.06 \Delta\end{array}$ & $0.63 \pm 0.04 \Delta$ & $1.76 \pm 0.24 \triangleleft$ \\
\hline HD-M & $257.52 \pm 13.48 \Delta$ & $2.41 \pm 0.34 \triangle$ & $\begin{array}{l}0.79 \pm \\
0.04 \Delta\end{array}$ & $0.65 \pm 0.03^{\Delta}$ & $1.58 \pm 0.06 \Delta$ \\
\hline HD-L & $\begin{array}{l}318.27 \pm \\
45.48\end{array}$ & $1.86 \pm 0.45$ & $0.60 \pm 0.12$ & $0.57 \pm 0.05$ & $1.23 \pm 0.16$ \\
\hline
\end{tabular}

Data are expressed as mean \pm SEM $(\mathrm{n}=10)$ and analyzed using one-way ANOVA. $p<0.05$ and " $p<0.01$ versus control group; $\Delta p<0.05$ and $\Delta \Delta p<0.01$ versus model group. HD-H: High-dose of HD; HD-M: Mid-dose of HD; HD-L: Low-dose of HD 

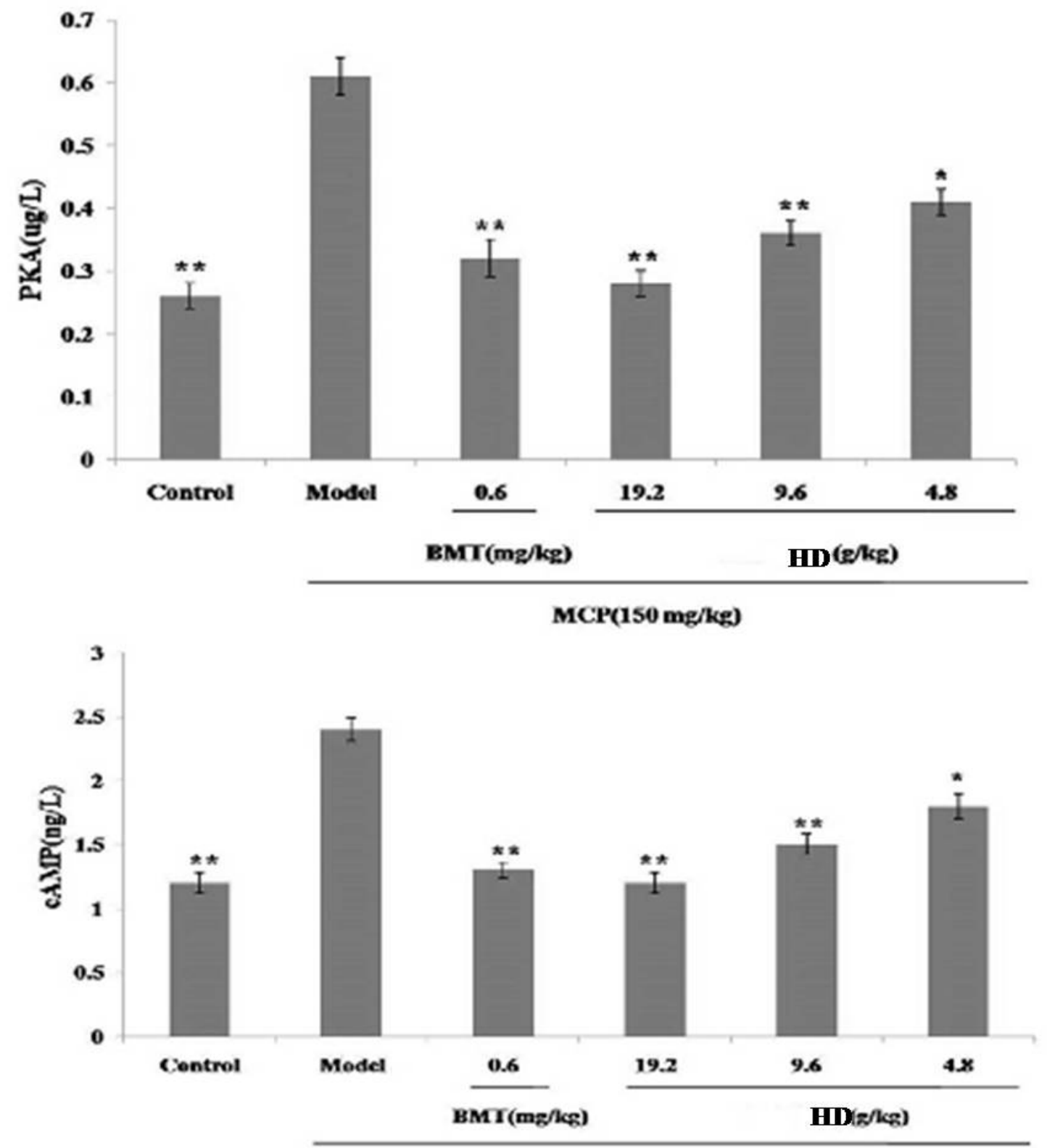

MCP(15a mg/kg)

Figure 1: Effect of HD on hypothalamus PKA and CAMP levels in hyperPRL rats. Data are expressed as mean \pm SEM $(n=10)$ and analyzed using one-way ANOVA. ${ }^{*} p<0.05$ and ${ }^{* *} p<0.01$ versus model group

The physiological and pathological roles of DR2 have been recognized in some organs such as brain and kidney $[19,20]$. In the adenohypophysis, the predominant dopamine receptor is the D2 receptor [21]. Transfection of the dopamine D2 receptor into a pituitary cell line results in a decrease in intracellular cAMP and inhibits prolactin secretion when dopamine is added to the cell culture [22,23]. Most conventional anti-hyperPRL agents reduce $P R L$ secretion through D2 receptor agonism in the hypothalamic neuroendocrine dopaminergic system, and cAMP/PKA signal transduction pathway is one of dopamine receptor classic pathways. In our study, HD inhibited PRL level via dopamine D2 receptor, and it reduced the
CAMP and PKA levels of hypothalamus in hyperPRL rats significantly. These suggested that HD showed anti-hyperPRL activity via dopamine $\mathrm{D} 2$ receptor.

\section{CONCLUSION}

Our studies demonstrated that HD show antihyperPRL activity via dopamine D2 receptor.

\section{DECLARATIONS}

\section{Conflict of Interest}

No conflict of interest associated with this work.

Trop J Pharm Res, December 2016; 15(12): 2644 


\section{Contribution of Authors}

The authors declare that this work was done by the authors named in this article and all liabilities pertaining to claims relating to the content of this article will be borne by them.

\section{Open Access}

This is an Open Access article that uses a funding model which does not charge readers or their institutions for access and distributed under the terms of the Creative Commons Attribution License (http://creativecommons.org/licenses/by 14.0) and the Budapest Open Access Initiative (http://www.budapestopenaccessinitiative.org/rea d), which permit unrestricted use, distribution, and reproduction in any medium, provided the original work is properly credited.

\section{REFERENCES}

1. Lee $D-Y$, Oh $K-L$, Yoon $B-K$. Prevalence of hyperprolactinemia in adolescents and young women with menstruation-related problem. Am $J$ Obstet Gynecol 2012; 206: 213.

2. Biller BM, Luciano A, Crosignani PG. Guidelines for the diagnosis and treatment of hyperprolactinemia. $J$ Reprod Med 1999; 44: 1075-1084.

3. Greer ME, Moraczewski T, Rakoff JS. Prevalence of hyperprolactinemia in anovulatory women. Obstet Gynecol 1980; 56: 65-69.

4. Gerhard Lutz. Hair loss and hyperprolactinemia in women. Dermato-Endocrinol 2012; 4: 73.

5. Yu-lee $L Y$, Luo GY, Book ML. Lactogenic hormone signal transduction. Biol Reprod 1998; 58: 295-301.

6. Webster J, Piscitell G, Polli A. A Comparison of Cabergoline and Bromocriptine in the Treatment of Hyperprolactinemic Amenorrhea. N Engl J Med 1994; 331: 904-909.

7. Mah PM, Webster J. Hyperprolactinemia: etiology, diagnosis and management. Semin Reprod Med. 2002; 20: 365-374.

8. Zhang ZJ, Tan $Q R$, Zhen XC, Tong $Y$. The potential benefits of herbal medicines for schizophrenia: from empirical observations to clinical trials (chapter 16).In: Hertzman M, Adler L, editors, "Clinical Trials in Psychopharmacology.UK: Wiley-Blackwell 2010; 311 35.

9. Xiong Wang, Yong-gang Chen, Li Ma, Zhi-hui Li, Ju-yi Li, Xin-guo Liu, Ji-li Zou, Jin-hu Wu. Effect of Chinese Medical Herbs-Huiru Decoction on Hyperprolactinemia and Hyperplasia of Mammary Gland in Mice. Afr J Tradit Complement Altern Med. 2013; 10: 24-35.

10. Fitzgerald P, Dinan TG. Prolactin and dopamine: what is the connection? J Psychopharmacol 2008; 22: 12-19.

11. Demaria JE, Nagy GM, Lerant AA, Fekete MI, Levenson CW, Freeman ME. Dopamine transporters participate in the physiological regulation of prolactin. Endocrinology 2000; 141: 366-74.

12. Laszczyńska M, S Uczanowska-G abowska S, Piasecka M, Skowron J, Debińska-Szymańska T. Germ cells with nuclear DNA fragmentation related to apoptotic cells in rat testis in experimental hyperprolactinemia induced by metoclopramide. Folia Histochem Cytobiol. 2002; 40: 163-4.

13. JA Gingrich, MG Caron. Recent advances in the molecular biology of dopamine receptors. Annu. Rev. Neurosci. 1993; 16: 299-321.

14. HZ Li, J Guo, J Gao. Role of dopamine D2 receptors in ischemia/reperfusion induced apoptosis of cultured neonatal rat cardiomyocytes. J. Biomed. Sci. 2011; 16: 18.

15. HZ Li, LP Han, CM Jiang. Effect of dopamine receptor 1 on apoptosis of cultured neonatal rat cardiomyocytes in simulated ischaemia/reperfusion. Basic. Clin. Pharmacol. Toxicol. 2008; 102: 329-336.

16. C Missale. Dopamine receptors: from structure to function. Physiol. Rev. 1998; 78: 189-225.

17. $P$ Greengard. The neurobiology of slow synaptic transmission. Science 2001; 294: 1024-1030.

18. JM Beaulieu, RR Gainetdinov, MG Caron. The Akt-GSK3 signaling cascade in the actions of dopamine. Trends. Pharmacol. Sci. 2007; 28: 166-172.

19. BK Madras. History of the discovery of the antipsychotic dopamine d2 receptor: a basis for the dopamine hypothesis of schizophrenia. J. Hist. Neurosci. 2013; 22: 62-78.

20. V Narkar, O Kunduzova, T Hussain, C Cambon, A Parini, $M$ Lokhandwala. Dopamine D2-like receptor agonist bromocriptine protects against ischemia/reperfusion injury in rat kidney. Kidney Int. 2004; 66: 633-64.

21. Cronin MJ. The role and direct measurement of the dopamine receptor(s) in the anterior pituitary. In: Muller EE, MacLeod RM, eds. Neuroendocrine perspectives 1982; 1: 169-210.

22. Nilsson C, Eriksson E. Partial dopamine D2 receptor agonists antagonize prolactin regulating $D 2$ receptors in a transfected clonal cell line $\left(G H_{4} Z R_{7}\right)$. Eur J Pharmacol 1992; 218: 205-11.

23. Audinot V, Rasolonjanahary $R$, Giros B. Couplage differentiel a la phospholipase $C$ des deux isoformes $d u$ recepteur dopaminergique $D 2$ transfectees dans la ligne GH4Cl. Ann Endocrinol. 1991; 52: 17N. 